\title{
Assessment of the decapod crustacean diversity in the Guayana Shield region aiming at conservation decisions
}

\author{
Célio Magalhães ${ }^{1,3}$ \& Guido Pereira ${ }^{2}$ \\ Biota Neotropica $v 7$ (n2) - http://www.biotaneotropica.org.br/v7n2/pt/abstract?article +bn02007022007 \\ Recebido em 13/09/06 \\ Versão Reformulada recebida em 04/04/07 \\ Publicado em 15/05/07 \\ ${ }^{1}$ Instituto Nacional de Pesquisas da Amazônia, CP 478, CEP 69011-970, Manaus, AM, Brazil \\ ${ }^{2}$ Instituto de Zoología Tropical, Universidad Central de Venezuela, \\ Apartado 47058, Caracas, 1041-A, Venezuela \\ ${ }^{3}$ Autor para correspondência: Célio Magalhães, e-mail: celiomag@inpa.gov.br
}

\begin{abstract}
Magalhães C. \& Pereira, G. Assessment of the decapod crustacean diversity in the Guayana Shield region aiming at conservation decisions. Biota Neotrop. May/Aug 2007 vol. 7, no. 2. http://www.biotaneotropica.org. br/v7n2/pt/abstract?article+bn02007022007. ISSN 1676-0603.

The current state of knowledge of freshwater decapod crustacean diversity of the Guayana Shield Region is briefly assessed, based upon information gathered from the scientific literature as well as unpublished data from academic theses, technical reports, and carcinological collections. The decapod fauna of the region is presently known to include 64 species and subspecies within six families and 17 genera. Diversity by countries, basins, and rivers is listed, comments on endemic, rare or threatened species are made, and information about relevant taxonomic literature is presented. Seven priority areas for conservation actions concerning crustacean decapods are suggested and related to the 25 priority areas defined by the Fishes and Freshwater Working Group at the Guayana Shield Conservation Priority Setting Workshop, held at Paramaribo (Suriname) in April 2002.
\end{abstract}

Keywords: biodiversity, checklist, freshwater crabs, freshwater shrimps, Amazon basin, Orinoco basin.

Resumo

Magalhães C. \& Pereira, G. Avaliação da diversidade de crustáceos decápodos na região do escudo das Guianas como subsídio a decisões de conservação. Biota Neotrop. May/Aug 2007 vol. 7, no. 2. http://www. biotaneotropica.org.br/v7n2/pt/abstract?article+bn02007022007. ISSN 1676-0603.

Avalia-se resumidamente a situação atual do conhecimento sobre a diversidade dos crustáceos decápodos de água doce da região do Escudo das Guianas com base em informações obtidas da literatura científica e dados inéditos de trabalhos acadêmicos, relatórios técnicos e coleções carcinológicas. A fauna de decápodos da região está atualmente constituída por 64 espécies e subespécies em seis famílias e 17 gêneros. Relaciona-se a diversidade por país, bacias e rios, faz-se comentários sobre espécies endêmicas, raras ou ameaçadas, e apresenta-se informações sobre a literatura taxonômica relevante de cada grupo. Em relação aos crustáceos decápodos, sugere-se sete áreas prioritárias para ações conservacionistas e relaciona-se essas áreas com as 25 áreas prioritárias definidas pelo Grupo de Trabalho em Peixes e Organismos Dulcícolas no "Guayana Shield Conservation Priority Setting Workshop", realizado em Paramaribo (Suriname), em abril de 2002.

Palavras-chave: biodiversidade, lista de espécies, caranguejos de água doce, camarões de água doce, bacia amazônica, bacia do Orinoco. 


\section{Introduction}

The Guayana Shield encompasses a large region of northern South America. It has an extensive and complex hydrographic network that includes several coastal river drainages and large portions of the Amazon and Orinoco River basins. A diversified fauna of freshwater decapod crustaceans occurs in the region. This fauna is constituted by several species of four families of shrimps (Atyidae, Euryrhynchidae, Palaemonidae and Sergestidae) and two of crabs (Pseudothelphusidae and Trichodactylidae). In the present contribution, we intend to briefly review the current state of knowledge about these crustacean groups by presenting a general overview of its diversity in the Guayana Shield, including a check list of the species according to the countries and hydrographic basins of this region, assessment of possible endemic, rare or threatened species, evaluate scientific efforts, and ultimately try to highlight the information gaps in order to support decisions for conservation priorities for this region.

\section{Material and Methods}

\section{Study area}

The Guayana Shield covers a large area of northern South America, broadly ranging from eastern Colombia to the west, to the Caribbean Sea and the Atlantic Ocean to the north and east, and to the Rio Negro and Rio Amazonas to the south. The region includes parts of Colombia, Venezuela, Brazil and almost all of Guyana, Suriname and French Guiana. The region is a very old cratonic area which underwent an orogenic cycle around 2,000 million years ago and has been tectonically stable for at least the last 1,700 million years (Bigarella \& Ferreira 1985). The region is marked by a series of mountain ranges, many reaching elevations higher than 2,000 m along the border of Brazil with Venezuela and the three Guianas, and by massive table mountains known as "tepuis", which dominate the Venezuelan portion of the Guayana Shield. Upland areas, characterized by altitudes lower then $800 \mathrm{~m}$, heavily eroded and covered largely by undisturbed tropical forest, extend throughout the remainder of the region. A diversity of environments can be found there, such as the swamps of the Orinoco Delta, the upland Gran Sabana, lowland tropical forest, peculiar white-sand savannas and shrublands of the upper Rio Negro Basin.

The hydrography of the region is complex. It is drained by the Orinoco River (mostly the right bank tributaries), the left bank tributaries of Amazon River and the coastal river drainages along the coastal strip of northern South America, from Guyana to the state of Amapá, in Brazil. The Amazon River tributaries include the Rio Negro and all its left bank tributaries. In the upper Rio Negro, some right bank affluents (Rio Vaupes/Uaupés, Rio Caqueta/Japurá) drain the Colombian relicts of the Guayana Shield, and an interconnection with the Orinoco Basin is made through the Casiquiare Channel. Other basin interconnections would also be possible along the Parima and Pacaraima Mountains (Brazilian-Venezuelan border) and through the inundated areas of the Rupununi, which connect the Essequibo and Cuyuni Rivers with the upper Rio Branco Basin (Rodríguez 1982b).

\section{Species assessment}

An accurate assessment of the decapod crustacean diversity in the Guayana Shield region is rather difficult, since knowledge of its taxonomic composition and distributional patterns is still far from complete. However, based on the existing documentation, an attempt to synthesize the current status of knowledge about the decapod fauna is made. Such synthesis relies mainly on information gathered from the scientific literature, but unpublished data from academic theses, technical reports and carcinological collections were also considered when available. These data were eventually obtained from the holdings of the following collections: Instituto Nacional de Pesquisas da Amazônia (INPA, Manaus), Instituto de Pesquisas Científicas e Tecnológicas do Amapá (IEPA, Macapá) and Museu Paraense Emílio Goeldi (MPEG, Belém), Brazil; Museo de Biologia de la Universidad Central de Venezuela (MB-UCV), Instituto Venezolano de Investigaciones Cientificas (IVIC), Caracas, Venezuela. A database was established considering entries for taxa (family, genus, species/ subspecies), authorship and year of the species description, country, basin, and reference source. This database was used for compiling species lists and distributions, and for comparing the specific richness of basins and rivers.

Synonymies and classification for each major group followed Rodríguez (1982a) for Pseudothelphusidae, Magalhães \& Türkay (1996a,b) for Trichodactylidae, and Holthuis $(1951,1952)$ for Palaemonidae. Family level classification follows Martin \& Davis (2001).

\section{Results}

\section{Status of knowledge of freshwater decapod crustaceans}

The freshwater decapods of the Guayana Shield region are fairly well known, although this knowledge is not uniform among the groups or countries, and almost all studies have been restricted to systematic and taxonomic aspects. Currently, there are six families, 17 genera and 64 species and subspecies of decapod crustaceans known to occur throughout the entire region (Appendix 1). The decapod fauna is constituted by the palaemonid shrimps, which is the most diverse group (39\% of the species/subspecies), the pseudothelphusid (33\%), the trichodactylid crabs (19\%), the euryrhynchid shrimps (6\%), and the atyid and sergestid shrimps (1.5\% each). The highest number of taxa is found in the Brazil and Venezuela (39), followed by Suriname (19) (Appendix 2), which mostly reflects the greater collecting and research efforts in these countries.

Most of the information about this fauna comes from sporadic collections and is scattered among the taxonomic literature. Perhaps the only systematic surveys of the decapod fauna in areas included in the Guayana Shield region are the inventories made by Lópes \& Pereira (1996, 1998), for the Orinoco Delta, and by Magalhães \& Pereira (2003), for the middle Caura River Basin.

There are some revisional works, either from the geographical or the taxonomic point of view, that provide useful information about the fauna of this region. Regional revisions were made by Young (1900) for Guyana, Holthuis (1959) for Suriname, and Rodríguez (1980) and Pereira (1982) for Venezuela; a list of the decapod species then known to tropical South America was provided by Rodríguez (1981). Taxonomic revisions, in which species occurring in the Guayana Shield region were mentioned, are available for the Pseudothelphusidae (Rathbun 1905, Bott 1969, Pretzmann 1972, Rodríguez 1982a), and Trichodactylidae crabs (Rathbun 1906, Bott 1969, Rodríguez 1992, Magalhães 1991, Magalhães \& Türkay 1996b), as well as for the Palaemonidae shrimps (Holthuis 1951, 1952, Tiefenbacher 1978).

Besides these, there are also some taxonomic and zoogeographical contributions with valuable information about the decapods of this region. Concerning the Brazilian portion of the region, one can mention the papers of Magalhães (1986, 1990), Magalhães \& Rodríguez (2002), and Magalhães et al. (2005) on the Brazilian pseudothelphusid crabs, Kensley \& Walker (1982) and Pimentel (2003) on some Amazonian palaemonid shrimps, as well as the manual of identification of the Brazilian freshwater decapod crustaceans (Melo 
2003a). The records for Colombia were done by Campos (1997) and Rodríguez \& Campos (1998) for pseudothelphusid crabs. The composition and distribution of the Venezuelan Guayana decapod fauna is better known: the freshwater shrimps were treated by Rodríguez (1982b), Pereira (1985, 1986, 1991), and Pereira et al. (1996); the pseudothelphusid crabs were studied by Rodríguez (1966), Rodríguez \& Pereira (1992), Rodríguez \& Suárez (1994), and Rodríguez \& Campos (1998). There are other contributions mentioning material from French Guiana (Miers 1877), Guyana (De Man 1900, Gordon 1935, Coifmann 1939) and Suriname (Holthuis 1993).

Just a few studies dealing with biological and ecological aspects of shrimps species that occur in the Guayana Shield region are available. The larval development of palaemonid shrimp was studied by Magalhães (1985, 1986/87, 1988a,b, 1989, 2000) and Magalhães \& Medeiros (1998). Ecological distribution and life history strategies were treated by Magalhães \& Walker (1988), Odinetz Collart \& Enriconi (1993) and Odinetz Collart \& Magalhães (1994), while Walker \& Ferreira (1985) studied the population dynamics of shrimp in a terra-firme forest stream in central Amazonia. Kowalczuk (2000) studied biological aspects of the decapod community in the upper Rio Branco, in Roraima.

The identification of the Guayana region decapod species may be carried out with a few revisional works, but some taxonomic contributions must be used in complement, particularly for the shrimps. The main papers suggested for decapod identification according to the taxonomic groups are the following: Atyidae: Hobbs \& Hart (1982). Palaemonidae: Holthuis (1951, 1952, 1959), Kensley \& Walker (1982), López \& Pereira (1996), Pereira (1985, 1986), Rodríguez (1980, 1982b), Tiefenbacher (1978), Melo (2003b). Pseudothelphusidae: Holthuis (1959), Magalhães (1986), Rodríguez (1980, 1982a), Pretzmann (1972), Rodríguez \& Campos (1998), Rodríguez \& Pereira (1992), Rodríguez \& Suárez (1994), Magalhães \& Rodríguez (2002), Magalhães (2003a). Sergestidae: Holthuis (1959), Omori (1975), Melo (2003b). Trichodactylidae: Holthuis (1959), Magalhães \& Türkay (1996a), Rodríguez (1992), Magalhães (2003a).

\section{Distribution of scientific efforts}

Regular scientific efforts are scattered and concentrated in a few places. In Brazil, collecting efforts are mainly directed to the middle and lower Rio Negro basin (state of Amazonas) and to the Yanomami Indians area, along the Brazilian-Venezuelan border (states of Amazonas and Roraima). Crustacean collecting expeditions have already been made in restricted areas of the Rio Araguari (state of Amapá), Rio Trombetas (state of Pará) and Rio Branco (state of Roraima) basins. In general, the Brazilian portion of the Guayana Shield has not yet been systematically surveyed for decapod crustaceans.

The Venezuelan Guayana seems to be somewhat better explored, especially the area of the upper Orinoco River and upper Cuyuni River basins, which is reflected by the many contributions of G. Pereira and G. Rodríguez and their collaborators. Recently, a systematic carcinological survey was performed in the Rio Caura (Magalhães \& Pereira 2003).

The decapod fauna of Suriname is quite well known and Holthuis (1959) included a report on the history of Suriname carcinology. His papers presented a very good picture of the composition and distribution of this fauna (Holthuis 1959, 1993). Currently, no efforts have been made to improve the knowledge about the decapod fauna of this country.

A similar situation is encountered in the other countries, where this knowledge comes from old or sporadic collecting efforts.

\section{Decapod diversity by hydrographic basins}

Taking into account the current figures, there is a great discrepancy in the species richness among the main hydrographic basins of the Guayana Shield region. The Amazon River Basin has the highest number of taxa (5 families, 16 genera and 41 species/subspecies), followed by the Orinoco ( 5 families, 11 genera and 35 species/subspecies), Suriname (6 families, 11 genera and 17 species) and Cuyuni (4 families, 8 genera and 11 species) River Basins (Appendix 3). The higher species richness of both Amazon and Orinoco River Basins was expected due to their age, size and heterogeneity of aquatic environments, as well as their long and complex geological history.

However, the distribution presented in Appendix 3 also suggests lack of information for many of the river systems, mainly due to shortage of detailed and systematic inventories. For instance, in Suriname, 17 species are known to occur in the Suriname River Basin, but much lower numbers are found in the nearby basins, such as the Marowijne/Maroni (10 species), Coppename ( 8 species) or Corantijn (4 species), in spite of their relatively similar sizes and geological histories. Perhaps due to the construction of the Brokopondo Dam, the Suriname River has received more faunistic inventory efforts than the others, thus reflecting higher species richness.

Considering only the main Amazon River tributaries draining Guayana Shield areas, distributional data are available for Rio Negro, Rio Uatumã, Rio Trombetas and Rio Jari; other rivers, such as Nhamundá and Paru do Leste, are completely unexplored concerning decapod fauna (Appendix 4). The Rio Jari sub-basin is very poorly studied and decapod records are incipient. There are records only for one palaemonid shrimp and four trichodactylid crabs species, which certainly do not allow even a preliminary analysis of its decapod species composition. The Rio Trombetas and Rio Uatumã show a similar number of taxa despite the former having a larger basin than the latter. However, the Rio Uatumã underwent more detailed faunistic inventories due both to the construction of the Balbina Hydroeletric Dam and the proximity of Manaus. The species richness for the Rio Uatumã should be even higher, considering that only its middle course was systematically surveyed. Species such as Macrobrachium amazonicum, M. brasiliense, Fredius denticulatus and $F$. reflexifrons, most probably occur in the basin, but are not yet recorded.

The largest left bank tributary of the Amazon, the Rio Negro has by far the highest species richness. Five families, 14 genera and 34 species/subspecies are distributed throughout this sub-basin. Some factors contribute to such richness. The size of the basin, which includes important tributaries such the Rio Branco and Rio Vaupés/ Uaupés; the complex geological history and hydrography, with existing basin interconections between the upper Rio Negro and the upper Orinoco River (through the Canal Casiquiare) and between some of the main tributaries of both rivers (Rio Branco with Rio Caura and Rio Caroni, along the Pacaraima Mountains), and between Rio Branco and the Essequibo River Basin (through the wetlands of the upper Rupununi River); and the diversity of environments that can be found within the basin, including mountain ranges and highplain areas, lowland tropical florest, peculiar white-sand savannas and shrublands, several black, clear and white water rivers, lakes, forest streams, large inland archipelagos and periodically inundanted areas.

The palaemonid shrimps are always the most diverse group, and the Orinoco River Basin has the highest species richness, with 19 species known to its Guayana portion of the basin. The pseudothelphusids show a higher number of species in the region than the trichodactylid crabs. Considering that the former family is typically a montane fauna while the latter is characteristically a lowland group (Rodríguez 1981), and as the elevation of most of the region considered here is above $300 \mathrm{~m}$, it should be expected that the pseudothelphusids be more diversified than the trichodactylids throughout the region.

\section{Distribution, endemism and rare or threatened species}

Distribution. Distribution maps of the species occurring in the Guayana Shield region can be found in Holthuis (1959), Rodríguez 
(1992), Magalhães \& Türkay (1996b), Magalhães \& Rodríguez (2002), Magalhães (2003a) and Melo (2003b). Some species have wide distributions in the lowlands of Amazon and/or Orinoco River Basins and also occur in the middle course of the tributaries draining the Guayana Shield. This is the case of some palaemonid (for instance, Euryrhynchus wrzesniowskii, Macrobrachium amazonicum, M. jelskii, M. brasiliense and Palaemonetes carteri) and sergestid (Acetes paraguayensis) shrimps, as well as the trichodactylid crabs. Similarly, adults of these palaemonid and atyid shrimps living in coastal river basins and whose life cycle depends upon mixohaline waters for accomplishing larval development can occur in the middle course of coastal river basins of Guyana, Suriname and French Guiana. Species such as Macrobrachium acanthurus, M. carcinus, $M$. olfersii and M. surinamicum fall into this category. Some pseudothelphusid crabs also show a broad distributional pattern, such as Fredius denticulatus, F. reflexifrons, and Kingsleya latifrons.

On the other hand, there are species that, judging from available documentation, have restricted distributions. A few trichodactylid crabs have so far only been found in certain Amazon River tributaries: Moreirocarcinus laevifrons in the Rio Negro and Rio Uatumã; Trichodactylus ehrhardti has been recorded in the lower Rio Negro, Rio Uatumã and Rio Trombetas; and Valdivia novemdentata is only known from upper Rio Negro. A similar situation applies to some pseudothelphusid crabs: Prionothelphusa eliasi and F. granulatus are distributed in the western portion of the Guayana Shield, while Kingsleya ytupora occurs in Rio Uatumã, Rio Trombetas and Rio Araguari Basins; it seems that Microthelphusa wymani and $M$. bolivari are restricted to Surinamese rivers and to the upper Rio Cuyuni, respectively, while Fredius chaffanjoni is known from the upper Rio Orinoco. Some palaemonid shrimps also show delimited distributions in the region: Pseudopalaemon spp. and Macrobrachium inpa are known so far only from the Rio Negro Basin; Macrobrachium quelchi occurs in the upper Mazaruni and Caroni River Basins; Euryrhynchus pemoni seems to be endemic to the Gran Sabana region, where it is much restricted to small creeks of high altitude plateaus in the upper Rio Caroni Basin; Macrobrachium atabapense, $M$. aracamuni and $M$. pectinatum have narrow distributions in the Venezuelan state of Amazonas; and Macrobrachium sp. 1 is known from the Rio Caura and Rio Caroni Basins.

Besides the species with wide distributions, there are some continental species with transbasin distributions: the trichodactylids Moreirocarcinus emarginatus, Poppiana dentata, Sylviocarcinus pictus and Valdivia serrata; the pseudothelphusids Kingsleya siolii, F. fittkaui, F. platyacanthus, F. stenolobus and F. estevisi estevisi; the palaemonids Euryrhynchus amazoniensis, Macrobrachium atabapense, M. cortezi, M. quelchi, and Palaemonetes ivonicus.

Many species are still known only from their type locality, for instance Valdivia haraldi (Trichodactylidae), Kingsleya besti, Microthelphusa somanni, M. rodriguezi, Fredius adpressus adpressus and Fredius estevisi siapensis (Pseudothelphusidae), Euryrhynchus pemoni, Pseudopalaemon sp. 1 and Macrobrachium aracamuni (Palaemonidae).

Endemism and rare species. The current knowledge about the taxonomic composition and distributional patterns of the decapod species, as well as the sporadic collecting efforts and low representativeness of the existing collections, do not allow conclusive statements about the recognition of endemic species occurring in the region. Usually, pseudothelphusid crabs have higher degrees of endemism, with species restricted to a single hydrographic basin or sub-basin (Rodríguez, 1982a). However, this assertion must be taken with caution regarding the Kingsleyini, the branch of the family occurring east of the Andes. Recent collections indicate that species once considered endemic to some river basins actually show broader distributions, as is the case for Fredius stenolobus, F. estevisi estevisi, $F$. platyacanthus and $F$. beccari. A similar situation was found to Macrobrachium quelchi, once known only from the upper Mazaruni River Basin and later found also in the upper Rio Caroni Basin (Pereira 1985). Perhaps more intensive and broader collecting efforts will reveal the same situation for many species currently thought to have restricted distributions.

Even so, it is reasonable to affirm that the Guayana Shield region is the endemic area for some species/subspecies. A cladistic and biogeographic analysis of the genus Fredius (Rodríguez \& Pereira 1992, Rodríguez \& Campos 1998) indicated that much of the group's evolution occurred in the Guayana region, particularly in hypothetical major basins comprising the present Orinoco, Essequibo and Cuyuni River Basins. Widespread species, such as $F$. reflexifrons and $F$. denticulatus, would have evolved in the nearby area of the Atlantic Guianas and the Amazon Basin. Therefore, most of the Fredius species and subspecies with restricted distributions could be considered endemic to the Guayana region. However, there is no such detailed analysis for other groups, and, judging by the available documentation, it is reasonable to believe that some other pseudothelphusid species could also be endemic to the region, as would be the case at least for the Microthelphusa spp. and Prionothelphusa eliasi. The genus Kingsleya can be found in southern tributaries of the Amazon River as well, and the distribution patterns of its species are not very well established yet (Magalhães 2003b, 2005). Any assumption of endemism for this genus in the region is therefore premature. Regarding the palaemonid shrimps, they usually are lowland species with wide distributions. Most of the species also occur elsewhere in the Amazon and Orinoco River Basins. However, a few species, such as Macrobrachium aracamuni, M. atabapense, $M$. cortezi, $M$. pectinatum, M. quelchi and Euryrhynchus pemoni, may prove to be endemic to the region, but it is too early to be certain.

Similarly, the status of a species as rare is also directly related to the collecting efforts and to its presence in existing collections. To date, there are several species that can be considered rare based on the few specimens available in collections and these are listed as follows: Palaemonidae (Euryrhynchus pemoni, Macrobrachium aracamuni, M. atabapense, M. pectinatum, M. quelchi, Macrobrachium sp. 1, Palaemonetes mercedae, Pseudopalaemon gouldingi, P. nigramnis, and Pseudopalaemon sp. 1), Pseudothelphusidae (Fredius adpressus adpressus, F. adpressus piaroensis, F. granulatus, Kingsleya besti, $K$. siolii, Microthelphusa bolivari, M. rodriguezi and M. somanni) and Trichodactylidae (Valdivia novemdentata and $V$. haraldi).

Threatened species. There is very little information on threat for freshwater decapod species. Pereira (in Rodríguez \& Rojas-Suárez 1995) mentioned two species of freshwater shrimps that we should be aware for conservation. One of them, Euryrhynchus pemoni from the Guayana Shield region, should be considered as threatened due to the low population and confined habitat. So far, no decapod species is known to be individually under threat. Although a few shrimp species are part of commercial fisheries, specially Macrobrachium amazonicum and M. carcinus in the lower Amazon River, the capture is essentially made by artisanal fishermen and consumed by locals (Moraes-Riodades \& Valenti 2001), an activity that does not compromise the species.

Perhaps the main threats to the species are environmental degradation that might affect the decapod community on a local basis. Deforestation and subsequent siltation of surrounding water bodies are potential threats to the decapod community, especially in "terra firme' (non-flooded) forest streams. Mining activities may also represent a potential threat to the carcinofauna, either due to environmental damage or to the poorly studied effect of the bioaccumulation of heavy metals through the trophic web. Species with restricted distributions 
may be more affected by such threats. However, to date, there is no information available to pinpoint species that might be severely threatened by problems like these.

Another potential threat to the decapod fauna is the introduction of exotic species. The Malaysian shrimp, Macrobrachium rosenbergii, is largely used for aquaculture purposes throughout the world. It was introduced in Venezuela and the Brazilian Amazon region, and it appears that wild populations have already been established in the Orinoco River Delta (Pereira et al. 1996) and, possibly, in the lower Amazon (Barros \& Silva 1997).

\section{Priority areas and themes for conservation and further research}

Definition of priority areas for conservation actions related to aquatic fauna should rely on a good knowledge about biodiversity, in particular taxonomic, distributional and ecological aspects. Although the taxonomy of most groups is fairly well known, there is a lot to be done concerning establishment of their distributional patterns and ecological interactions. More comprehensive and systematic inventories should be carried out in order to better document the alpha and beta diversity of some hydrographic sub-basins of the Guayana Shield region.
Biological and ecological studies will contribute to management actions for sustainable use and conservation of aquatic resources.

Definition of priority areas for conservation and further research should take into account those areas with a number of species of restricted or patchy distribution, and areas with faunal interconnections. Concerning the decapod fauna, and based on the current documentation, briefly presented above, the following areas can be suggested for receiving priority status (Figure 1):

a) Upper Rio Negro: high species richness and place of occurrence for many species with restricted or patchy distribution, as well as faunistic interconnections with the Orinoco River Basin and with the Colombian relicts of the Guayana Shield;

b) Middle Rio Negro: high species richness and presence of diversified environments due to the extent of the periodically flooded forest and the intricate island system;

c) Upper Rio Branco basin: high species richness and faunistic interconnections either with the Orinoco (through the Rio Caroni and Rio Caura) or the Essequibo River Basins, as well as presence of a peculiar environment (savanna), which could favor diversity of other crustacean groups;

d) Upper and/or middle course of rivers coming from the mountains along the Brazilian/Guianas borders: null or low degree of knowledge about alfa and beta diversity (especially the

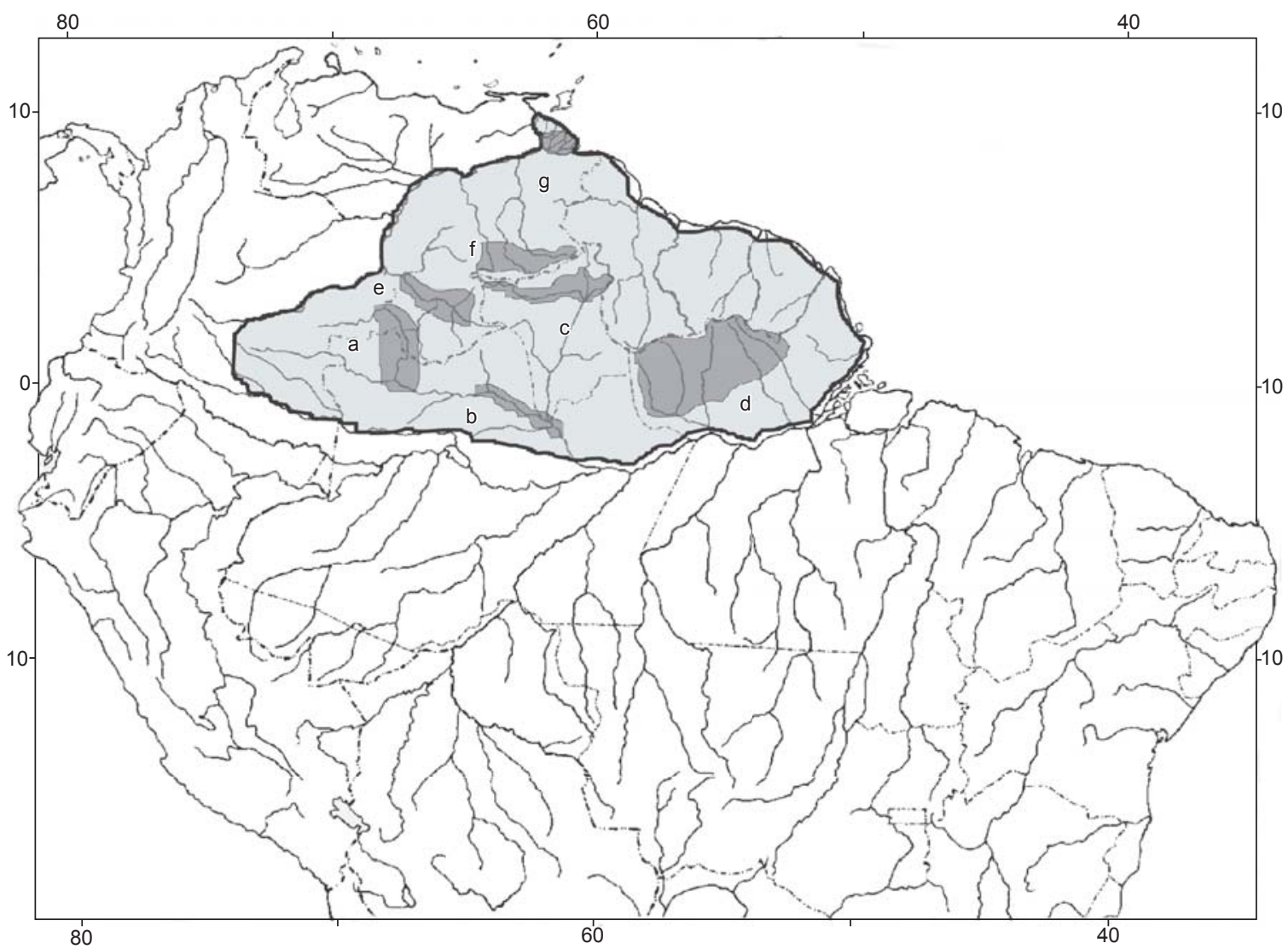

Figure 1. Map of the Northern South America, highlighting the Guayana Shield region as defined in this paper and the priority areas suggested for conservation and further research of decapod crustaceans: a) Upper Rio Negro; b) Middle Rio Negro; c) Upper Rio Branco basin; d) Upper and/or middle course of rivers from the Brazilian/Guyanas borders; e) Upper Orinoco; f) Upper Caura and Caroni; and g) Orinoco delta.

Figura 1. Mapa do norte da América do Sul, realçando a região do escudo das Guianas conforme definido neste artigo e as áreas prioritárias sugeridas para conservação e incremento de pesquisas sobre crustáceos decápodos: a) alto rio Negro; b) médio rio Negro; c) bacia do alto rio Branco; d) cursos alto e/ou médio de rios procedentes da fronteira Brasil/Guianas; e) alto rio Orinoco; f) alto rio Caura e alto rio Caroni; e g) delta do Orinoco. 
Amazon River tributaries in the states of Pará and Amapá), as well as possible faunistic interconnections with coastal river basins of Guiana, Suriname and French Guiana;

e) Upper Orinoco River: high species richness and place of occurrence for many species with restricted or punctual distribution, faunistic interconnections with the Amazon Basin, as well as presence of a peculiar environment such as Tepuys which could favor diversity of other crustaceans groups;

f) Upper Caura and Caroni rivers: high species richness, endemism and faunistic interconnections either with the Orinoco, Essequibo River Basins, as well as presence of a peculiar environment (high altitude savannah, and tepuys), which could favor diversity of other crustaceans groups. This area already includes the Gran Sabana and Canaima National Parks; and

g) Orinoco Delta: the largest wet land in the region, also transitional zone of estuarine and freshwater environment; high species richness and faunistic interconnections. There is a Biosphere Reserve already in this area.

The Freshwater Working Group at the Guayana Shield Conservation Priority Setting Workshop (http://www.guayanashield.org/ev.php), held at Paramaribo in April 2002, indicated 25 priority areas for future studies and conservation based on information from fishes and decapod crustaceans (Lasso et al. 2003). These areas are distributed along three broad subregional areas, which are: eastern lowlands, southern lowlands, and a complex region comprising the uplands, highlands and the lowlands of the northwestern area of the Guayana Shield. According to the Working Group's analysis, improvement of taxonomic, biologic and ecologic studies, as well as establishment of conservation actions, in these 25 areas would affect six different faunistic groups for fishes and crustaceans, which are: (1) Areas of the Guayanas in the eastern zone from the Essequibo to the Oyapock; (2) Areas in the north-central part that drain into the Orinoco; (3) Río Ventuari Basin in the northwest of the Orinoco; (4) River basins in the southwestern extension of the Shield that includes the region of Chiribiquete which, as far as known, has a special biogeographic relationship to both the Rio Negro and the Río Caquetá; (5) Upper and middle Rio Negro and Rio Trombetas area; (6) A series of inter-basins headwater areas that drain off large mountain and tepuy areas.

The priority areas specifically for crustaceans suggested above would be included in these 25 regions, and any conservation measure that might be taken in the future will certainly protect the decapod diversity of the Guayana Shield region.

\section{Acknowledgments}

We thank M. Cohn-Haft and G. Nakamura for revising the English.

\section{References}

BARROS, M.P. \& SILVA, L.M.A. 1997. Registro de introdução da espécie exótica Macrobrachium rosenbergii (De Man, 1879) (Crustacea, Decapoda, Palaemonidae), em águas do estado do Pará, Brasil. Bol. Mus. Para. Emilio Goeldi, Zool. 13(1):31-37.

BIGARELLA, J.J. \& FERREIRA, A.M.M. 1985. Amazonian geology and the Pleistocene and the Cenozoic environments and paleoclimates. In Key Environments. Amazonia (Prance, G.T. \& T.E. Lovejoy, eds.). Pergamon Press, Oxford, p. 49-71.

BOTT, R. 1969. Die Süßwasserkrabben Süd-Amerikas und ihre Stammesgeschichte. Eine Revision der Trichodactylidae und der Pseudothelphusidae östlich der Anden (Crustacea, Decapoda). Abh. senckenb. naturforsch. Ges. 518:1-94.

CAMPOS, M.R. 1997. Primeros registros de la tribu Kingsleyini (Crustacea: Decapoda: Pseudothelphusidae) para Colombia. Caldasia 19(1-2):269-277.
COIFMANN, I. 1939. Potamonidi della Guiana Inglese raccolti dal Prof. Nello Beccari. Arch. zool. ital. 27:93-116.

De MAN, J.G. 1900. Crustacea. In Report on a collection made by Messrs. F.V. McConnell and J.J. Quelch at Mount Roraima in British Guiana (Lankester, E.R., ed.). Trans. Linn. Soc. Lond., Zool. (2)8:57-64, pl. 6.

GORDON, I. 1935. On new or imperfectly known species of Crustacea Macrura. J. Linn. Soc. Lond., Zool. 39:307-351.

HOBBS, H.H. \& HART, C.W. 1982. The shrimp genus Atya (Decapoda: Atyidae). Smithson. Contrib. Zool. 364:1-143, figs. 1-53.

HOLTHUIS, L.B. 1951. A general revision of the Palaemonidae (Crustacea, Decapoda, Natantia) of the Americas. I. The subfamilies Euryrhynchinae and Pontoniinae. Occasional Paper, Allan Hancock Fundation Publications 11:1-332, pls. 1-63.

HOLTHUIS, L.B. 1952. A general revision of the Palaemonidae (Crustacea, Decapoda, Natantia) of the Americas. II. The subfamily Palaemoninae. Occasional Paper, Allan Hancock Fundation Publications 12:1-396, pls. 1-55.

HOLTHUIS, L. B. 1959. The Crustacea Decapoda of Suriname. Zool. Verh. 44:1-296, figs. 1-68.

HOLTHUIS, L.B. 1993. The decapod Crustacea of Brokopondo lake, Suriname. Nauplius 1:1-12.

KENSLEY, B. \& WALKER, I. 1982. Palaemonid shrimps from the Amazon basin, Brazil (Crustacea, Decapoda, Natantia). Smithson. Contrib. Zool. 362:1-28.

KOWALCZUK, V.G.L. 2000. Assembléia de Crustacea Decapoda da margem direita do alto Rio Branco, Roraima. Tese de doutorado, Universidade Federal do Paraná, Curitiba.

LASSO, C.A., CHERNOFF, B. \& MAGALHÃES, C. 2003. Peixes e ecologia de água doce. In Prioridades de Conservação para o Escuda das Guianas. Consenso 2002 (Huber, O. \& M.N. Foster, Orgs.). Conservation International, Washington, D.C., p.9-11.

LÓPEZ, B. \& PEREIRA, G. 1996. Inventario de los crustaceos decapodos de las zonas alta y media del delta del Rio Orinoco, Venezuela. Acta Biol. Venez. 16(3):45-64.

LÓPEZ, B. \& PEREIRA, G. 1998. Actualización del inventario de crustáceos decápodos del Delta del Orinoco. In El Rio Orinoco. Aprovechamiento Sustentable (López Sánchez, J.L., I.I. Saavedra Cuadra \& M. Dubois Martínez, eds.). Universidad Central de Venezuela, Caracas, p.76-85. [Memorias de las Primeras Jornadas Venezolanas de Investigación sobre el rio Orinoco.]

MAGALHÃES, C. 1985. Desenvolvimento larval obtido em laboratório de palaemonídeos da Região Amazônica. I. Macrobrachium amazonicum (Heller, 1862) (Crustacea, Decapoda). Amazoniana 9(2):247-274.

MAGALHÃES, C. 1986. Revisão taxonômica dos caranguejos de água doce brasileiros da família Pseudothelphusidae (Crustacea, Decapoda). Amazoniana 9(4):609-636.

MAGALHÃES, C. 1986/87. The larval development of palaemonid shrimps from the Amazon Region reared in the laboratory. V. The abbreviated development of Pseudopalaemon chryseus Kensley \& Walker, 1982 (Crustacea: Decapoda: Palaemonidae). Acta Amazonica 16/17(nº único):95-108.

MAGALHÃES, C. 1988a. The larval development of palaemonid shrimps from the Amazon Region reared in the laboratory. II. Extremely abbreviated larval development in Euryrhynchus Miers, 1877 (Decapoda, Euryrhynchinae). Crustaceana 55(1):39-52.

MAGALHÃES, C. 1988b. The larval development of palaemonid shrimps from the Amazon Region reared in the laboratory. III. Extremely abbreviated larval development of Palaemonetes (Palaemonetes) mercedae Pereira, 1986 (Crustacea, Decapoda). Stud. neotrop. Fauna Environ. 23(1):1-8.

MAGALHÃES, C. 1989. The larval development of palaemonid shrimps from the Amazon Region reared in the laboratory. VI. Abbreviated development of Macrobrachium nattereri (Heller, 1862) (Crustacea: Decapoda). Amazoniana 10(4):379-392.

MAGALHÃES, C. 1990. A new species of the genus Kingsleya from Amazonia, with a modified key for the Brazilian Pseudothelphusidae (Crustacea: Decapoda: Brachyura). Zool. Meded. 63(21):275-281. 
MAGALHÃES, C. 1991. Revisão taxonômica dos caranguejos dulcícolas da família Trichodactylidae (Crustacea: Decapoda: Brachyura). Tese de doutorado, Universidade de São Paulo, São Paulo.

MAGALHÃES, C. 2000. Abbreviated larval development of Macrobrachium jelskii (Miers, 1877) (Crustacea: Decapoda: Palaemonidae) from the Rio Solimões floodplain, Brazil, reared in the laboratory. Nauplius 8(1):1-15.

MAGALHÃES, C. 2003a. Famílias Pseudothelphusidae e Trichodactylidae. In Manual de Identificação dos Crustacea Decapoda de Água Doce do Brasil (G.A.S. de Melo, ed.). Editora Loyola, São Paulo, p.143-287.

MAGALHÃES, C. 2003b. The occurrence of freshwater crabs (Crustacea: Decapoda: Pseudothelphusidae, Trichodactylidae) in the Rio Xingu, Amazon Region, Brazil, with description of a new species of Pseudothelphusidae. Amazoniana, 17(3/4):377-386.

MAGALHÃES, C. 2005. A new species of freshwater crab (Crustacea: Decapoda: Pseudothelphusidae) from the southeastern Amazon Basin. Nauplius, 12(2):99-107[2004].

MAGALHÃES, C., ABRUNHOSA, F.A., PEREIRA, M.O. \& MELO, M.A. 2005. New records of Fredius denticulatus (H. Milne-Edwards, 1853) and $F$. reflexiforns (Ortmann, 1897), and the eastern limits of the distribution of pseudothelphusid crabs (Crustacea: Decapoda) in Brazil. Acta Amazonica, 35(1):93-96.

MAGALHÃES, C. \& MEDEIROS, N. 1998. The larval development of palaemonid shrimps from the Amazon Region reared in the laboratory. VI. Abbreviated development of Pseudopalaemon amazonensis Ramos-Porto, 1979 (Crustacea: Decapoda: Caridea). Acta Amazonica 28(4):433-448.

MAGALHÃES, C. \& PEREIRA, G. 2003. Decapod crustaceans survey in the middle Río Caura Basin: species richness, habitat, zoogeographical aspects, and conservation implications. In A Biological Assessment of the Aquatic Ecosystems of the Caura River Basin, Bolívar State, Venezuela (B. Chernoff, A. Machado-Allison, K. Riseng \& J. R. Montambault, eds). Conservation International, Washington, DC, p. 56-63, 282-284 (Appendix 11). [RAP Bulletin of Biological Assessment 28]

MAGALHÃES, C. \& RODRÍGUEZ, G. 2002. The systematic and biogeographical status of Fredius reflexifrons (Ortmann, 1897) and Fredius fittkaui (Bott, 1967) (Crustacea: Brachyura: Pseudothelphusidae) from the Amazon and Atlantic Guianas River Basins. Acta Amazonica 32(4):677-689.

MAGALHÃES, C. \& TÜRKAY, M. 1996a. Taxonomy of the Neotropical freshwater crab family Trichodactylidae I. The generic system with description of some new genera (Crustacea: Decapoda: Brachyura). Senckenbergiana biol. 75(1/2):63-95.

MAGALHÃES, C. \& TÜRKAY, M. 1996b. Taxonomy of the Neotropical freshwater crab family Trichodactylidae II. The genera Forsteria, Melocarcinus, Sylviocarcinus, and Zilchiopsis (Crustacea: Decapoda: Brachyura). Senckenbergiana biol. 75(1/2): 97-130.

MAGALHÃES, C. \& WALKER, I. 1988. Larval development and ecological distribution of central amazonian palaemonid shrimps (Decapoda, Caridea). Crustaceana 55(3):279-292.

MARTIN, J.W. \& DAVIS, G.E. 2001. An updated classification of the recent Crustacea. Natural History Museum of Los Angeles County Science Series, 39:1-124.

MELO, G.A.S. (ed.) 2003a. Manual de Identificação dos Crustacea Decapoda de Água Doce do Brasil (G.A.S. de Melo, ed.), Editora Loyola, São Paulo.

MELO, G.A.S. 2003b. Famílias Atyidae, Palaemonidae e Sergestidae. In Manual de Identificação dos Crustacea Decapoda de Água Doce do Brasil (G.A.S. de Melo, ed.), Editora Loyola, São Paulo, p.289-415.

MIERS, E.J. 1877. On a collection of Crustacea, Decapoda and Isopoda, chiefly from South America, with descriptions of new genera and species. Proc. Zool. Soc. Lond. 1877:653-679, pls 66-69.

MORAES-RIODADES, P.M.C. \& VALENTI, W.C. 2001. Freshwater prawn farming in Brazilian Amazonia shows potential for economic, social development. Global Aquaculture Advocate, 4(5):73-74.

ODINETZ-COLLART, O. \& ENRICONI, A. 1993. Estrátegias reprodutivas e alguns aspectos demográficos do camarão Palaemonetes carteri
Gordon, 1935 na Amazônia central, rio Negro. Acta Amazonica 23(2-3):227-243.

ODINETZ COLLART, O. \& MAGALHÃES, C. 1994. Ecological constraints and life history strategies of palaemonid prawns in Amazonia. Verh. Internat. Verein. Limnol. 25:2460-2467.

OMORI, M. 1975. The systematics, biogeography, and fishery of epipelagic shrimps of the genus Acetes (Crustacea, Decapoda, Sergestidae). Bull. Ocean Res. Inst., Univ. Tokyo (7):1-89.

PEREIRA, G. 1982. Los camarones del genero Macrobrachium (Decapoda, Palaemonidae) de Venezuela. Trabajo de Ascenso, Universidad Central de Venezuela, Caracas.

PEREIRA, G. 1985. Freshwater shrimps from Venezuela III: Macrobrachium quelchi (De Man) and Euryrhynchus pemoni, n. sp. (Crustacea: Decapoda: Palaemonidae) from La Gran Sabana. Proc. Biol. Soc. Wash. 98(3):615-621.

PEREIRA, G. 1986. Freshwater shrimps from Venezuela I: Seven new species of Palaemoninae (Crustacea: Decapoda: Palaemonidae). Proc. Biol. Soc. Wash. 99(2):98-213.

PEREIRA, G. 1991. Camarones de agua dulce de Venezuela II: Nuevas adiciones en las familias Atyidae y Palaemonidae (Crustacea: decapoda: Caridea). Acta Biol. Venez. 13(1-2):75-88.

PEREIRA, G., EGÁÑEZ, H. \& MONENTE, J.A. 1996. Primer reporte de una población silvestre, reproductiva de Macrobrachium rosenbergii (De Man) (Crustacea, Decapoda, Palaemonidae) en Venezuela. Acta Biol. Venez. 16(3):93-95.

PIMENTEL, F.R. 2003. Taxonomia dos camarões de água doce (Crustacea: Decapoda: Palaemonidae, Euryrhynchidae, Sergestidae) da Amazônia Oriental: estados do Amapá e Pará. Dissertação de Mestrado, Instituto Nacional de Pesquisas da Amazônia, Manaus.

PRETZMANN, G. 1972. Die Pseudothelphusidae (Crustacea Brachyura). Zoologica 42(120) pt. 1:1-182.

RATHBUN, M.J. 1905. Les Crabes d'eau douce (Potamonidae). Nouv. Arch. Mus. Hist. Nat. 7(4):159-321, pls. I-XXII.

RATHBUN, M. J. 1906. Les crabes d'eau douce (Potamonidae). Nouv. Arch. Mus. Hist. Nat. 8(4):33-122.

RODRÍGUEZ, J.P. \& ROJAS-SUÁREZ, F. 1995. Libro Rojo de la Fauna Venezolana". PROVITA, Caracas.

RODRÍGUEZ, G. 1966. Three new species of Pseudothelphusa from Venezuela (Crustacea Brachyura Potamonidae). Zool. Meded. 41(19):259-267, pls. 1-3.

RODRÍGUEZ, G. 1980. Crustaceos Decapodos de Venezuela. IVIC, Caracas.

RODRÍGUEZ, G. 1981. Decapoda. In: Aquatic Biota of Tropical South America, Part 1: Arthropoda (Hurlbert, S.H., G. Rodríguez \& N.D. Santos, eds.). San Diego State University, San Diego, p.41-51.

RODRÍGUEZ, G. 1982a. Les crabes d'eau douce d'Amerique. Famille des Pseudothelphusidae. Editions ORSTOM, Paris, 224p. [Collection Faune Tropicale, 22]

RODRÍGUEZ, G. 1982b. Fresh-water shrimps (Crustacea, Decapoda, Natantia) of the Orinoco basin and the Venezuelan Guayana. J. Crustac. Biol. 2(3):378-391

RODRÍGUEZ. G. 1992. The Freshwater Crabs of America. Family Trichodactylidae and Supplement to the Family Pseudothelphusidae. Editions ORSTOM, Paris, 189p. [Collection Faune Tropicale 31]

RODRÍGUEZ, G. \& CAMPOS, M.R. 1998. A cladistic revision of the genus Fredius (Crustacea: Decapoda: Pseudothelphusidae) and its significance to the biogeography of the Guianan lowlands of South America. J. Nat. Hist. 32:763-775.

RODRÍGUEZ, G. \& PEREIRA, G. 1992. New species, cladistic relationships and biogeography of the genus Fredius (Crustacea: Decapoda: Pseudothelphusidae) from South America. J. Crustac. Biol. 12:298-311.

RODRÍGUEZ, G. \& SUÁREZ, H. 1994. Fredius stenolobus, a new species of freshwater crab (Decapoda: Brachyura: Pseudothelphusidae) from the Venezuelan Guiana. Proc. Biol. Soc. Wash. 107(1):132-136. 
TIEFENBACHER, L. 1978. Zur Systematik und Verbreitung der Euryrhynchinae (Decapoda, Natantia, Palaemonidae). Crustaceana 35(2):178-189.

WALKER, I. \& FERREIRA, M.J.N. 1985. On the population dynamics and ecology of the shrimp species (Crustacea, Decapoda, Natantia) in Central Amazonian River Taruma-Mirim. Oecologia 66:264-270.
YOUNG, C.G. 1900. The stalked-eye Crustacea of British Guiana, West Indies and Bermuda. J.M. Watkins, London. 


\section{Appendix}

Table 1. Check list of decapod crustacean species distributed in the Guayana Shield region.

Tabela 1. Lista de espécies de crustáceos decápodos distribuidos na região do escudo das Guianas.

\section{ATYIDAE}

Atya gabonensis Giebel

EURYRHYNCHIDAE

Euryrhynchus amazoniensis Tiefenbacher

E. burchelli Calman

E. pemoni Pereira

E. wrzesniowskii Miers

\section{PALAEMONIDAE}

Macrobrachium acanthurus (Wiegmann)

M. amazonicum (Heller)

M. aracamuni Rodriguez

M. atabapense Pereira

M. brasiliense (Heller)

M. carcinus (Linnaeus)

M. cortezi Rodriguez

M. ferreirai Kensley \& Walker

M. inpa Kensley \& Walker

M. jelskii (Miers)

M. nattereri (Heller)

M. olfersii (Wiegmann)

M. pectinatum Pereira

M. quelchi De Man

M. rosenbergii (De Man)

M. sp. n. 1

M. surinamicum Holthuis

Palaemonetes carteri Gordon

$P$. ivonicus Holthuis

P. mercedae Pereira

Pseudopalaemon amazonensis Ramos Porto

P. chryseus Kensley \& Walker

$P$. gouldingi Kensley \& Walker

P. nigramnis Kensley \& Walker

P. sp. n. 1

SERGESTIDAE
Pseudothelphusidae

Fredius adpressus adpressus Rodriguez \& Pereira

F. adpressus piaroensis Rodriguez \& Pereira

F. beccarii (Coifmann)

F. chaffanjoni (Rathbun)

F. denticulatus (H. Milne-Edwards)

F. estevisi estevisi Rodriguez

F. estevisi siapensis Rodriguez \& Pereira

F. fitkaui Bott

F. granulatus Rodriguez \& Campos

F. platyacanthus Rodriguez \& Pereira

F. reflexifrons (Ortmann)

F. stenolobus Rodriguez \& Suarez

Kingsleya besti Magalhães

$K$. latifrons (Randall)

$K$ siolii Bott

K. ytupora Magalhães

Microthelphusa bolivari Rodriguez

M. rodriguezi Pretzmann

M. somanni (Bott)

M. wymani (Rathbun)

Prionothelphusa eliasi Rodriguez

Trichodactylidae

Dilocarcinus septemdentatus (Herbst)

Forsteria venezuelensis (Rathbun)

Moreirocarcinus emarginatus (H. Milne-Edwards)

M. laevifrons (Moreira)

Poppiana dentata (Randall)

Sylviocarcinus devillei $\mathrm{H}$. Milne-Edwards

S. pictus (H. Milne-Edwards)

Trichodactylus ehrhardti Bott

T. faxoni Rathbun

$V$ aldivia haraldi Bott

$V$. novemdentata (Pretzmann)

V. serrata White 
Table 2. Check list of decapod crustacean species distributed in the Guayana Shield region according to countries.

Tabela 2. Lista de espécies de crustáceos decápodos distribuidos na região do escudo das Guianas conforme os países.

\begin{tabular}{|c|c|c|c|c|c|c|}
\hline & Brazil & Colombia & F. Guiana & Guiana & Suriname & Venezuela \\
\hline \multicolumn{7}{|l|}{ ATYIDAE } \\
\hline Atya gabonensis & & & & & $\bullet$ & \\
\hline \multicolumn{7}{|l|}{ EURYRHYNCHIDAE } \\
\hline Euryrhynchus amazoniensis & $\bullet$ & & & & & $\bullet$ \\
\hline E. burchelli & $\bullet$ & & & & & \\
\hline E. pemoni & & & & & & $\bullet$ \\
\hline E. wrzesniowskii & $\bullet$ & & $\bullet$ & $\bullet$ & $\bullet$ & \\
\hline \multicolumn{7}{|l|}{ PALAEMONIDAE } \\
\hline Macrobrachium acanthurus & & & & & $\bullet$ & \\
\hline M. amazonicum & $\bullet$ & & & $\bullet$ & $\bullet$ & $\bullet$ \\
\hline M. aracamuni & & & & & & $\bullet$ \\
\hline M. atabapense & & & & & & $\bullet$ \\
\hline M. brasiliense & $\bullet$ & & $\bullet$ & $\bullet$ & $\bullet$ & $\bullet$ \\
\hline M. carcinus & & & & & - & $\bullet$ \\
\hline M. cortezi & & & & & & $\bullet$ \\
\hline M. ferreirai & $\bullet$ & & & & & \\
\hline M. inpa & $\bullet$ & & & & & \\
\hline M. jelskii & $\bullet$ & & $\bullet$ & & $\bullet$ & $\bullet$ \\
\hline M. nattereri & $\bullet$ & & $\bullet$ & & & $\bullet$ \\
\hline M. olfersi & & & & & $\bullet$ & \\
\hline M. pectinatum & & & & & & $\bullet$ \\
\hline M. quelchi & & & & $\bullet$ & & $\bullet$ \\
\hline M. rosenbergii & & & & & & $\bullet$ \\
\hline$M$. sp. n. 1 & & & & & & $\bullet$ \\
\hline M. surinamicum & & & & $\bullet$ & $\bullet$ & $\bullet$ \\
\hline Palaemonetes carteri & $\bullet$ & & $\bullet$ & $\bullet$ & $\bullet$ & $\bullet$ \\
\hline P. ivonicus & & & & & & $\bullet$ \\
\hline P. mercedae & $\bullet$ & & & & & $\bullet$ \\
\hline Pseudopalaemon amazonensis & $\bullet$ & & & & & $\bullet$ \\
\hline P. chryseus & $\bullet$ & & & & & \\
\hline P. gouldingi & $\bullet$ & & & & & $\bullet$ \\
\hline P. nigramnis & $\bullet$ & & & & & \\
\hline P. sp. n. 1 & & & & & & $\bullet$ \\
\hline \multicolumn{7}{|l|}{ PSEUDOTHELPHUSIDAE } \\
\hline Fredius adpressus adpressus & & & & & & $\bullet$ \\
\hline F. adpressus piaroensis & & & & & & $\bullet$ \\
\hline F. beccarii & & & & $\bullet$ & & $\bullet$ \\
\hline F. chaffanjoni & & & & & & $\bullet$ \\
\hline F. denticulatus & $\bullet$ & & $\bullet$ & & $\bullet$ & \\
\hline F. estevisi estevisi & $\bullet$ & & & & & $\bullet$ \\
\hline F. estevisi siapensis & & & & & & $\bullet$ \\
\hline F. fittkaui & $\bullet$ & & & $\bullet$ & & $\bullet$ \\
\hline F. granulatus & & $\bullet$ & & & & \\
\hline F. platyacanthus & $\bullet$ & & & & & $\bullet$ \\
\hline F. reflexifrons & $\bullet$ & & $\bullet$ & & $\bullet$ & \\
\hline F. stenolobus & $\bullet$ & & & & & $\bullet$ \\
\hline Kingsleya besti & $\bullet$ & & & & & \\
\hline K. latifrons & $\bullet$ & & $\bullet$ & $\bullet$ & $\bullet$ & \\
\hline K. siolii & $\bullet$ & & & & $\bullet$ & \\
\hline K. ytupora & $\bullet$ & & & & & \\
\hline
\end{tabular}


Table 2. Continued..

\begin{tabular}{|c|c|c|c|c|c|c|}
\hline & Brazil & Colombia & F. Guiana & Guiana & Suriname & Venezuela \\
\hline Microthelphusa bolivari & & & & & & $\bullet$ \\
\hline M.rodriguezi & & & & $\bullet$ & & \\
\hline M.somanni & $\bullet$ & & & & & \\
\hline M.wymani & & & & & $\bullet$ & \\
\hline Prionothelphusa eliasi & $\bullet$ & $\bullet$ & & & & - \\
\hline \multicolumn{7}{|l|}{ SERGESTIDAE } \\
\hline Acetes paraguayensis & $\bullet$ & & & & $\bullet$ & $\bullet$ \\
\hline \multicolumn{7}{|l|}{ TRICHODACTYLIDAE } \\
\hline Dilocarcinus septemdentatus & $\bullet$ & & $\bullet$ & & $\bullet$ & \\
\hline Forsteria venezuelensis & & & & & & - \\
\hline Moreirocarcinus emarginatus & $\bullet$ & $\bullet$ & & & & • \\
\hline M. laevifrons & $\bullet$ & & & & & $\bullet$ \\
\hline Poppiana dentata & $\bullet$ & & & & $\bullet$ & $\bullet$ \\
\hline Sylviocarcinus devillei & $\bullet$ & & & & & \\
\hline S. pictus & $\bullet$ & & & $\bullet$ & & - \\
\hline Trichodactylus ehrhardti & $\bullet$ & & & & & \\
\hline T. faxoni & $\bullet$ & & & & & \\
\hline Valdivia haraldi & $\bullet$ & & & & & \\
\hline V. novemdentata & $\bullet$ & & & & & \\
\hline V. serrata & $\bullet$ & $\bullet$ & & $\bullet$ & $\bullet$ & $\bullet$ \\
\hline
\end{tabular}




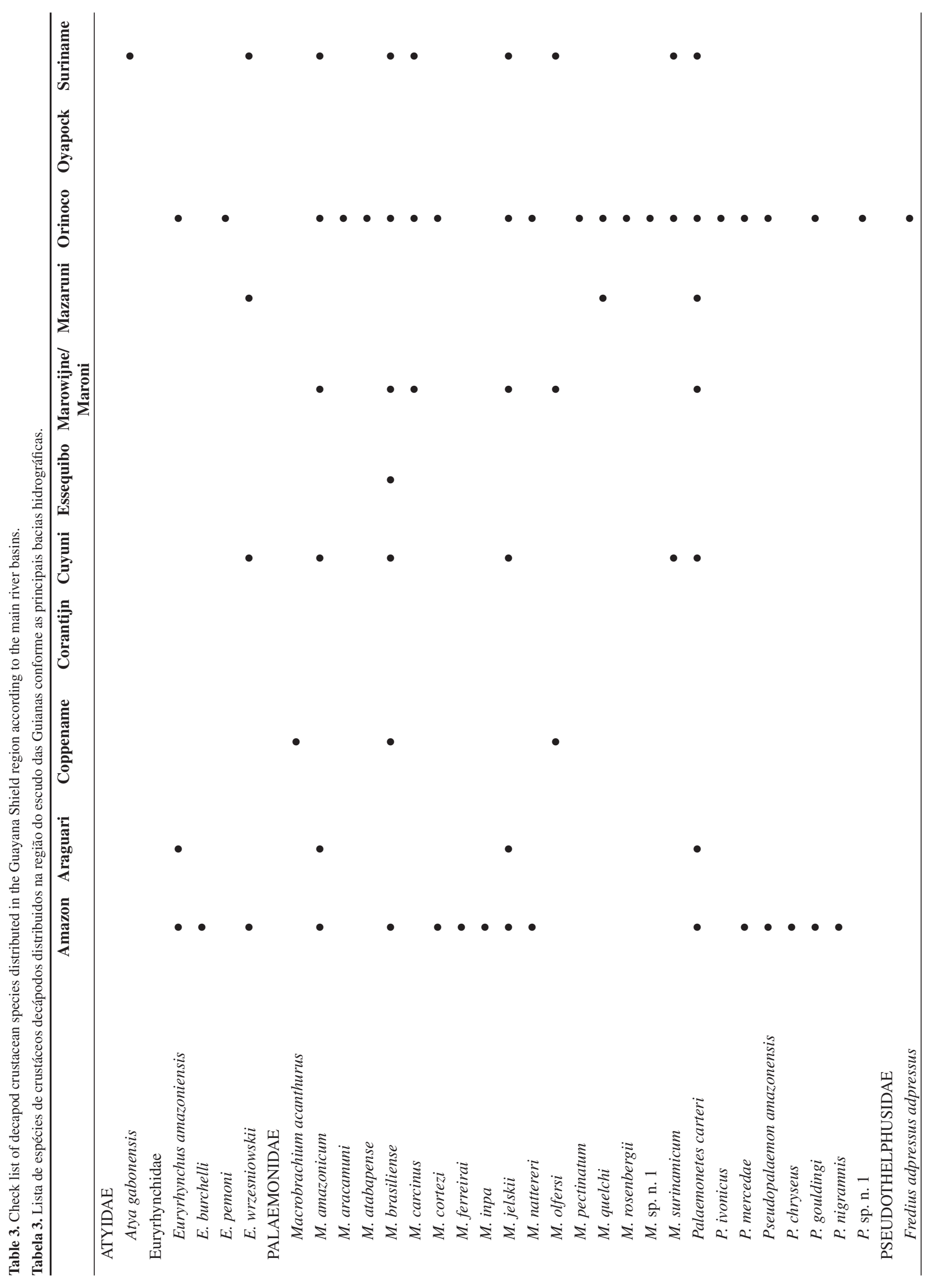

http://www.biotaneotropica.org.br 

Table 4. Check list of decapod crustacean species distributed in the Amazon River main tributaries coming from the Guayana Shield region.

Tabela 4. Lista de espécies de crustáceos decápodos distribuidos nos principais tributários do rio Amazonas oriundos da região do escudo das Guianas.

\begin{tabular}{|c|c|c|c|c|c|c|}
\hline & Rio Negro & Rio Uatumã & $\begin{array}{c}\text { Rio } \\
\text { Nhamundá }\end{array}$ & $\begin{array}{c}\text { Rio } \\
\text { Trombetas }\end{array}$ & $\begin{array}{l}\text { Rio Paru do } \\
\text { Leste }\end{array}$ & Rio Jari \\
\hline \multicolumn{7}{|l|}{ EURYRHYNCHIDAE } \\
\hline Euryrhynchus amazoniensis & $\bullet$ & $\bullet$ & & $\bullet$ & & \\
\hline E. burchelli & $\bullet$ & $\bullet$ & & & & \\
\hline E. wrzesniowskii & & $\bullet$ & & $\bullet$ & & \\
\hline \multicolumn{7}{|l|}{ PALAEMONIDAE } \\
\hline Macrobrachium amazonicum & $\bullet$ & & & $\bullet$ & & \\
\hline M. brasiliense & $\bullet$ & & & $\bullet$ & & $\bullet$ \\
\hline M. cortezi & $\bullet$ & & & & & \\
\hline M. ferreirai & $\bullet$ & $\bullet$ & & & & \\
\hline M. inpa & $\bullet$ & & & & & \\
\hline M. jelskii & $\bullet$ & & & & & \\
\hline M. nattereri & $\bullet$ & $\bullet$ & & $\bullet$ & & \\
\hline Palaemonetes carteri & $\bullet$ & $\bullet$ & & $\bullet$ & & \\
\hline P. mercedae & $\bullet$ & $\bullet$ & & & & \\
\hline Pseudopalaemon amazonensis & $\bullet$ & & & & & \\
\hline P. chryseus & $\bullet$ & $\bullet$ & & $\bullet$ & & \\
\hline P. gouldingi & $\bullet$ & & & & & \\
\hline P. nigramnis & $\bullet$ & & & & & \\
\hline \multicolumn{7}{|l|}{ PSEUDOTHELPHUSIDAE } \\
\hline F. denticulatus & $\bullet$ & & & & & \\
\hline F. estevisi estevisi & $\bullet$ & & & & & \\
\hline F. fittkaui & $\bullet$ & & & & & \\
\hline F. platyacanthus & $\bullet$ & & & & & \\
\hline F. reflexifrons & $\bullet$ & & & $? \bullet$ & & \\
\hline F. stenolobus & $\bullet$ & & & & & \\
\hline Kingsleya besti & $\bullet$ & & & & & \\
\hline K. latifrons & $\bullet$ & $\bullet$ & & $\bullet$ & & \\
\hline K. siolii & & & & $\bullet$ & & \\
\hline K. ytupora & & $\bullet$ & & $\bullet$ & & \\
\hline Microthelphusa somanni & $\bullet$ & & & & & \\
\hline Prionothelphusa eliasi & $\bullet$ & & & & & \\
\hline \multicolumn{7}{|l|}{ SERGESTIDAE } \\
\hline Acetes paraguayensis & $\bullet$ & & & & & \\
\hline \multicolumn{7}{|l|}{ TRICHODACTYLIDAE } \\
\hline \multicolumn{7}{|l|}{ Dilocarcinus septemdentatus } \\
\hline Moreirocarcinus emarginatus & $\bullet$ & & & & & \\
\hline M. laevifrons & $\bullet$ & $\bullet$ & & & & \\
\hline Poppiana dentata & $\bullet$ & & & & & \\
\hline Sylviocarcinus devillei & & & & & & $\bullet$ \\
\hline S. pictus & $\bullet$ & $\bullet$ & & $\bullet$ & & $\bullet$ \\
\hline Trichodactylus ehrhardti & $\bullet$ & $\bullet$ & & $\bullet$ & & \\
\hline T. faxoni & & & & & & $\bullet$ \\
\hline Valdivia haraldi & $\bullet$ & & & & & \\
\hline$V$. novemdentata & $\bullet$ & & & & & \\
\hline V. serrata & $\bullet$ & $\bullet$ & & $\bullet$ & & $\bullet$ \\
\hline
\end{tabular}

